\title{
Framing Malaysia in the News Coverage of Indonesian Television
}

\author{
Hamedi M. Adnan \\ Amri Dunan
}

Department of Media Studies, Faculty of Art and Social Sciences of Malaya University, 50603 Kuala Lumpur hamedi@um.edu.my

\section{Doi:10.5901/mjss.2016.v7n2s1p45}

\section{Abstract}

During the administration period of Susilo Bambang Yudhoyono (SBY), Indonesia-Malaysia relationship became worse due to certain issues. There are three important issues affected relationship between Indonesia-Malaysia_political issue (Ambalat issue), economic issue (Indonesian migrant worker-TKI) and cultural issue (Pendet dance). The question rise up in IndonesiaMalaysia relationship caused by the response and the sensitively from Indonesian which affected by the media framing, included media television. This research is to identify how framing is created and identify the media television framing. This research uses framing analysis of 'Television News' model developed from Gamson \& Mogdiliani (1989) model and uses the inductive qualitative analysis process developed from the model of Van Gorp (2005/2010). The model refers to the identification method in verbal framing or nonverbal framing with the matrix method. In-depth interviews were conducted to 12 peopleseach four from television stations Metro TV, TV One and TVRI. Each of them consists of a reporter, cameraman, producer and redaction leader. This in-depth interview proposed to know 'how' and 'why' the verbal and nonverbal framing is done by the stations. Triangulation between framing analysis of 'television news' model, in-depth interview and the observation shows that the basic ideology such as nationalism from the media owner affect the media framing on Malaysia. They also emphasize on the nonverbal framing strategy by using camera angle, graphic, cartoon or illustration and sound bite to frame issues related to Malaysia.

Keywords: Indonesia-Malaysia conflict, framing, news television, visual reporting

\section{Introduction}

Why the demonstration in front of the Malaysia Embassy in Jakarta is being widely reported by Indonesian television? Why the visual burning of Malaysia flag during the demonstration being showed and so close up? And why the scene where demonstrators sing of Indonesian national song being shown during the news reporting? These kinds of questions are being raised as the result of framing process towards certain issue or incident by the media. According to Gamson and Mogdiliani (1989), framing should be focussed on how the incident being framed and then showed them to public or viewer.

Framing process normally done by television based on the ideology they followed. For those media, the tendency towards economic ideologies to increase the rating will attract advertisement in their programme, especially in news reporting. The television which tends towards political ideologies paid more attention to public attraction in their programmes, especially international news reporting which related to the counties where conflict is occurred. The ideology stand of Pancasila by Indonesian television was also influence by the press and the broadcast system in the country. Under the rule of President Soeharto from 1967 to 1998, Indonesian press system was called as press of Pancasila. However, when Rajawali Citra Television Indonesia (RCTI) became the first private television in 1987, the capitalism ideology slowly carry out the framing process in Indonesian television (Sen \& Hill, 2007: 112). Thus, capitalism press system is partially responsible to create information characteristic, for example, personal, non-contextual, emphasize on action and depiction, and more stereotype (lyengar, 1991; Hallin, 1986).

Generally, relationship between Indonesia and Malaysia can be divided into three frames. The first frame was during the Indonesia-Malaysia confrontation in 1963-1966, where there was 'Ganyang (crush) Malaysia' frame under the regime of Soekarno (Syed Othman, 1999). Second, was the frame of 'Saudara Serumpun' (family brotherhood) during the New Order regime under President Soeharto and the third frame is 'Malingsia' (Malaysian thief) during the period of Reformasi (1999-2004). Most Indonesian media is familiar with these frames and they seems to be aware of what side to turn in incidents between the two neighbours during the period above. The tense relationship between Indonesia and 
Malaysia is normally caused by different responses from Indonesian as a result of framing by the media. Indonesian press misleads their pubic by created the negative perception towards Malaysia by different methods to rise up the nationalism spirit and anti-Malaysia sentiment.

This purpose of this research is to clarify the framing method, rectify the factors and identify the media ideology base in Indonesian television. Three main national television studios in Indonesia, Metro TV, TV One, and TVRI will be studied, on the news reporting about the relationship between Indonesia and Malaysia. Metro TV and TV One are private televisions which normally broadcast a special reporting in the conflict between the two countries. As such, they are always deeply involves in critical reporting towards Malaysia. The other station, TVRI is more diplomatic as it is owned by the state and as such, its stand will always reflect the official stand of the Indonesian government. Commonly, there are three main issues involve in Indonesia-Malaysia relationship, which is politics, social and cultural. As such, this framing analysis will concentrated to three different issues of politics in Ambalat maritime boundaries, social issues in Indonesian migrant worker (TKI) and cultural issue in Pendet dance.

Ambalat is a tiny island in the east coast of Borneo. Its strategic location off Borneo where the northern part is belong to Malaysia while the southern is owned by Indonesia is the subject of a territorial dispute between the two countries. For several decades, disputes arise due to issues such as intrusion among fisherman of both nations and the serious one involved military force. In March 2005, it was reported that a Malaysian navy vessel is ramming Indonesian military ship. However, the report was later retracted by Indonesian national news agency, Kompas when the inaccurate report has already embarrass both countries. In June 2009, relations became tense when Malaysia was accused of violating Indonesia's maritime boundary for several times. Later, the Indonesian sea patrol was reported to pursuing a Malaysian Navy off the Ambalat sea. This news tighten the bilateral relations between the two neighbours.

Indonesian migrant workers in Malaysia is another issue which often alienate the two countries. Most of them which are low-skilled and work in domestic sector are prone to exploitation, extortion, physical and sexual abuses, suffered by those enduring human trafficking (Eng Lai, Collins \& Yeoh, 2013). Several cases of abuses upon Indonesian migrant worker has been reported and the media at home usually provide coverage which ignite people to hate Malaysia. The last issue to be focused in this article is Pendet, a traditional danced originally from Bali, Indonesia. The dance was used in a "Visit Malaysia Year" commercial campaigns to illustrate the attractiveness of the country and Indonesian claimed that the commercial seems to indicate the dance was something indigenously Malaysian (Antaranews.com). As a result, strong protests have been launched by media in Indonesia where Malaysia was called as "Malingsia" or "a thief".

\section{Verbal Strategy and Nonverbal Framing}

Two strategies for the media framing on image, issue or opinion are verbal and nonverbal framing. The verbal framing is the strategy to frame the reputation or image using the verbal language. Symbol or verbal massage is all kind of symbols using one or verb (Mulyana, 2011: 260). Almost all speech can be categorised as the speech with purpose, which is the effort to interact verbally with other peoples. Tuchman (1980: 104-132) explained that using certain symbol or language can determine the narrative format and meanings.

Non-verbal framing involved usage of nonverbal language to create a frame for certain issue. According to Samovar and Porter (1991) in Mulyana (2011:343), the nonverbal communication involved all stimulation or behaviour with or without propose which meaningful to own self or other people. To know the reporter's view or perspective to choose on verbal or non-verbal language in news reporting, the framing analysis is used. For Gamson and Mogdiliani (1989: 3), the reporter's view can be determined as the idea to show the issue or incident and being discussed by public which related to him/her. In other words, it is the scheme using by reporters to determine the meaning of massage they accepted or delivered.

Framing analysis normally involved how public scheme can be activated by the massage received. The basic frame normally involved the option and the projection. The frame in the media can lead us to the definition and gives the attraction to the incidents reported and tries to indistinct the other incident (Entman, 1993). Anything left behind is contributed to the framing power. On the most general stage, framing means the small changing in the presentation script, such as the visual presentation. Visual frame is different compared to the published news and discussion for the news reporting. According to Messaris and Abraham (2001: 220), the specification for visual in the visual frame, iconicity, indexicality and implicitness are the efficient tools to frame and explain the massage ideology.

Messaris and Abraham (2001:215) said that visual frame maybe create the less affect to the public compared with words. However, the visual element can delivered the massage easily and frame the words. In the visual frame context, the attendance of the massage or the picture can help to determine the news incident (Entman, 1993). This statement is totally opposite with the public believe that picture is non-neutral (Hulteng, 1985; Tagg, 1988). Even without image, 
picture needs to capture the reality complex (Messaris and Abraham, 2001).

Reporter's visual cannot be excluded in the movement framing process. They may need to follow the guide line to produce the objective report but they can deliver the dominant news to the targeted audience (Entman, 1993). Therefore, visual elements should also be count. Kaszmierzak (2001) treated the visual elements as the language to produce and deliver the thinking and reality image. This language is created by their context symbols. Messaris and Abraham (2001: 216) said that the relationship between most verbs is the purity convention of social issues. This is because the relation between the picture and the meaning on the analogy. According to them, the quality picture is the direct hints, not the reality (Messaris \& Abraham, 2001: 217). Visual is therefore, the representative and interpretation which allowed people to create or express the thinking and image about reality.

\section{The Research}

Based on the argumentation, the research objective of this research has been decided as below.

i. Identify the framing of Indonesian media television (Metro TV, TV One, and TVRI) on the issues of Ambalat, TKI, and cultural (Pendet dance).

ii. Identify the framing method in news reporting on Malaysian reputation by the Indonesian television (Metro TV, TV One, and TVRI) on the issues of Ambalat, TKI, and cultural (Pendet dance).

iii. Identify the most important factors for the framing of Indonesian television (Metro TV, TV One, and TVRI) on the issues of Ambalat, TKI, and cultural (Pendet dance).

iv. Identify the most influent ideology for Indonesian television (Metro TV, TV One, and TVRI) framing on the issues of Ambalat, TKI, and cultural (Pendet dance).

From the five objectives above, the research will try to identify if the press is under pressure from the state or whether ideologies from the state or media owner will influent the framing.

From the research objectives, several queries regarding to the news reporting by Indonesia television are raised:

i. What is the framing of Indonesian television on the issues of Ambalat, TKI, and cultural (Pendet dance)?

ii. What is the new model analysis on television news framing to produce verbal and non-verbal frame to strengthen the media frame?

iii. How can the framing be done by Indonesian television on the issues of Ambalat, TKI, and cultural (Pendet dance)?

iv. What are the most influent factors for the framing of Indonesian television on the issues of Ambalat, TKI, and cultural (Pendet dance)?

V. What is the most influent ideology for Indonesian television framing on the issues of Ambalat, TKI, and cultural (Pendet dance)?

\section{Methodology}

This research uses 'Television News' model of framing analysis which extended from the Gamson \& Mogdiliani (1989) model and will also uses the Van Gorp (2005/2010) inductive qualitative analysis procedure. 'Television News' model for framing analysis refers to a way to identify framing method by verbal or nonverbal using the matric method from television on an issue, incident or case. Television frame is the matric frame which involves combination framing analysis of verbal and nonverbal.

This matric frame composed by four devices, framing devices (verbal), reasoning devices (verbal), framing devices (nonverbal), and reasoning devices (nonverbal). 'Television News' model for framing analysis is used in the nonverbal framing and reasoning devices (nonverbal). Framing devices (nonverbal) is formed by audio presentation strategy (language, illustration and atmosphere) and visual presentation strategy (movement and camera angle, graphic and cartoon). Reasoning devices (nonverbal) is formed by roots analysis, appeals to principal and consequences, and it is actually same with reasoning devices (verbal). To complete the findings, triangulation is used to combine and compare the analysis findings for model television news reporting and interview and observation. Three steps are used to complete the methods of this research.

\section{Framing Analysis of 'Television News' Model}

In the first step, the matric frame is used to framing analysis of 'Television News'. For example, framing analysis of text and news broadcast by Metro TV on $27^{\text {th }}$ May 2011 can be refers to Table 1 below. 
Table 1: Combination of verbal and nonverbal framing for Ambalat issue by Metro TV

\begin{tabular}{|c|c|c|c|}
\hline \multicolumn{4}{|c|}{ Frame of Metro TV: Threaten from Malaysia } \\
\hline Frame (verbal): Threaten fron & Neighboring Country Warship to Ambalat & $\begin{array}{r}\text { Frame (nonverbal): Eviction } 0 \\
\text { by }\end{array}$ & $\begin{array}{l}\text { ff Malaysian Ship from Ambalat } \\
\text { KRI }\end{array}$ \\
\hline Framing devices (verbal) & Reasoning Devices (verbal) & Framing devices (nonverbal) & Reasoning Devices (nonverbal) \\
\hline $\begin{array}{c}\text { Catchphrases (contras): } \\
\text { Neighboring country army vs. TNI } \\
\text { (National Indonesian Army) Navy } \\
\text { Depiction: } \\
\text { Neighboring country as the label } \\
\text { Metaphors: } \\
\text { 'Continue being heat' is the } \\
\text { metaphor for Ambalat's situation. } \\
\text { Depiction: } \\
\text { 'Trouble' means the negative } \\
\text { Metaphors: } \\
\text { 'Ignite' shows the TNI Navy are } \\
\text { brave }\end{array}$ & $\begin{array}{c}\text { Roots: } \\
\text { Malaysia army always trespassing, TNI Navy } \\
\text { take the action to kick out them } \\
\text { Appeals } \\
\text { to principle: } \\
\text { Moral massage bring up that TNI Navy } \\
\text { prepared to protect Indonesia from threaten by } \\
\text { Malaysia army } \\
\text { Consequences: } \\
\text { To bring up the wish of Malaysia to respect } \\
\text { Indonesia. }\end{array}$ & $\begin{array}{c}\text { Language: } \\
\text { Occur everyday } \\
\text { Graphic: } \\
\text { Title being publish in three } \\
\text { version to emphasize the } \\
\text { frame } \\
\text { Angle: } \\
\text { High angle for negative } \\
\text { image } \\
\text { Angle: } \\
\text { Pictures showed the action } \\
\text { taken by TNI Navy } \\
\text { Sound bite: } \\
\text { To bring out Malaysia in } \\
\text { negative position. } \\
\text { Sound-up to emphasize the } \\
\text { Malaysia negative image }\end{array}$ & $\begin{array}{c}\text { Roots: } \\
\text { Malaysia warship enters to } \\
\text { Indonesia water everyday } \\
\text { Appeals } \\
\text { to principle: } \\
\text { KRI do the right thing while } \\
\text { Malaysia did the wrong thing } \\
\text { Consequences: } \\
\text { The ruler and the public support } \\
\text { the action taken by TNI Navy }\end{array}$ \\
\hline
\end{tabular}

Before the verbal and nonverbal frame is combined as shown on the table above, the verbal and nonverbal frame need to be selected in the matrix frame. Thus, a suitable method should be followed with paradigm constructive spirit and comparison method as the principle to make the inductive code by verbal and non-verbal. It includes open coding, axe coding and selective coding, from beginning until the end (Glaser \& Strauss, 1967/1971; Van Gorp, 2010).

The second step is in-depth interview with the framing parties like reporters, news producers and the editorial leaders. This in-depth interview is to identify the framing method and the reason they create such symbols in the paper, picture and voice. Besides, observation is done in the television stations, as well as to get text and audio-visual data for framing analysis. The data involve 195 broadcast news clips for Metro TV, 149 clips for TV One and 16 clips for TVRI which related to issues of Ambalat, TKI and cultural (Pendet dance). The clips of news broadcast were shown to public in the programs Metro Hari Ini (Metro TV), Kabar Petang (TV One), and Warta Malam (TVRI) from $1^{\text {st }}$ January 2011 until 10th October 2011.

The last step is triangulation where all data are being combined and processed to create conclusion. This first conclusion will be tested repeatedly to get a complete conclusion. Triangulation process is done several times to ensure the above method was combined to come out with a satisfied answer. This step purposed is to emphasize on the validity, reliability and the objectivity from the research finding.

\section{Discussion: Ideology and Media Ownership}

Based on the framing analysis, it is obvious that Metro TV is more actively broadcast news that tends to give negative reputation to Malaysia. This trend is more on strategy of nonverbal framing such as graphic, sound bite, intonation and atmosphere. The negative reputation framing on Malaysia is done through graphic; super impose title on "Klaim (claim) Malaysia" from the beginning of the news broadcast until the end. These framing is align with the history and establishment objective of Metro TV by Surya Paloh to improve the dignity and standard of Indonesia through television and media. It seems that in order to raise the spirit of patriotism among Indonesian, Metro TV portrays negative reputation to Malaysia.

At the same time, competition for rating is always tense between Metro TV and TV One. It reflects the political feud between owners of the two stations-Surya Paloh, owner of Metro TV and Aburizal Bakrie, owner of TV One. Metro TV is supportive to National Democrat Party (NasDem) established by Surya Paloh while TV One is more towards Golkar, the party leads by Bakrie. The support of Metro TV is shown in advertisement, especially during the Pemilihan Umum (general election) times and the direct participation of the television stations in activities for National Democrat Party. It also consistently used the "Changing Movement", as the official slogan for Surya Paloh political ideology. Thus, patriotism and Surya Paloh political agenda can be considered as political ideology in the framing on the negative reporting of 
Malaysia in the issue mentioned above. Reporters, producers and editorial leaders interviewed stated that they understand of Surya Paloh's political stand and the nationalism approach of the media to be framed. According to one of the producer, if there is no comment from the higher authority that means the news reporting met the media owner's expectation.

Economic factors, such as to get better rating and advertisement sales was also considered as well as social factors such as giving information and education to all Indonesian. However, consideration of politic became the basic ideology for Metro TV to frame Malaysia for bad reputation. News about conflict of Indonesia-Malaysia is always filled with patriotic song like Maju tak Gentar (Move without fear) together with a clip of TNI army in training for the background.

It was also clear that negative portrayal of Malaysia in Metro TV is reflect to the sentiment, political ideology, and nationalism belongs to the owner, Surya Paloh. This trend is more focus on strategy of nonverbal framing such as graphic, cartoon, sound bite, intonation, and atmosphere. Besides, strategy in audio presentation, illustration, music with high and emotive tempo, and even cartoon were used to raise nationalism among Indonesian to hate Malaysia.

These framing is align with the history and objective of TV One, established by Aburizal Bakrie, a rich politician leader for Golkar party and among the early candidates in Indonesian Presidential Election in 2014. The objective of the station is similar to Metro TV, to improve dignity and standard of Indonesian through television and media. In order to raise patriotic spirit among Indonesian, TV One presents the negative reporting about Malaysia. As with Surya Paloh, Aburizal Bakrie also has dignity and patriotisms which is reflected in the news coverage of TV One. According to an editorial leader, TV One is always support and gives a positive coverage of Aburizal Bakrie. That, according to him, is a kind of editorial independent to support the truth. As the editorial policy aligns with the vision, mission and the journalistic practice, Aburizal Bakrie, the owner for TV One will always support the policy.

So, the patriotism and Aburizal Bakrie's characteristic act as politic ideology in the framing on the negative reputation of Malaysia in the issue mentioned above in TV One. According to reporter, producer and the editorial leader whose knows Aburizal Bakrie, they understand that his characteristic and his nationalism will influent the framing and media routine. An editorial leader said that they are free to edit the news from Kuala Lumpur on any cases. If there is no comment from Jakarta that means the reporting met Aburizal Bakrie's expectation. Economic factors, such as rating and advertisement and social factors are less dominant in the news that negatively framed Malaysia.

Therefore, political factor became the basic ideology for TV One to negatively framed Malaysia. Negative reputation towards Malaysia never except from sentiment politic ideology, nationalism and the ideology belongs to Aburizal Bakrie, the TV One owner. Framing analysis on the television news reporting model towards the Ambalat, TKI and cultural issues (Pendet dance) also obviously found that TVRI tends to bring out negative coverage about Malaysia. As with Metro TV, TVRI is more focus on the nonverbal framing strategies such as graphic, cartoon, sound bite, intonation and atmosphere. Besides, the strategy of presentation, voice, illustration, and music were used.

These framing is align to the history and founding objective of TVRI. As a state owned television station, TVRI is supportive towards the government policies. Since its inception in 1962, TVRI has always play the role to reflect the government stand of policy and issues. The national television station was used by different regimes from Old Order to Reformasi and to current regime to convey official policy of the government. A senior editorial leader of TVRI stated that as the national leader, the President is the main source for news during the conflict between Indonesia-Malaysia. As the only television station with full coverage in the whole country, part of the mission for TVRI is to unite Indonesian and protect the dignity of the nation. As such, whoever becomes the President of Indonesia, his policies will be supported by TVRI.

The strong character of President Susilo Bambang Yudhoyono (SBY) has dominantly influent TVRI framing on issues of Ambalat, TKI and cultural (tari Pendet). As the country leader, President SBY is known as a politic personage and state army general with high nationalism spirit. As such, the strong political ideology and reputation of the President is strongly affecting TVRI negative framing towards Malaysia in the three issues researched. Reporters, producers and editorial leaders of TVRI stated that they understand of the mission and vision of the station, and also clearly understand the nationalism image bring up by the President. They also realized that their nationalism will affect the framing process and the media routine process. For example, nationalistic value was inserted when the pictures of Malaysian warship enters Indonesian territory on Ambalat news coverage. A reporter of TVRI said that he was called to implement this value through the coverage.

Hence, the political ideology is basic in TVRI negative frame of Malaysia. The conflict between Indonesia-Malaysia is effectively relayed through the graphic and sound bite presentation. The President's stand-point can be seen in the coverage of those issues. 


\section{Conclusion}

Metro TV, TV One and TVRI generally tried to put Malaysia as a high-headed "Little Brother" who didn't appreciate and respect the Big Brother of Indonesia. Thus, Malaysia was negatively framed in the news reporting of the three television stations. Based on the television news reporting model framing analysis, Metro TV and TV One almost use the same framing, which is the conflict frame. For the Ambalat issue, Metro TV framed it as "threaten from Malaysia", while TV One uses the frame "Malaysia attack". For the TKI issue, Metro TV framed it as "torment to TKI" while TV One framed it as "the death of TKI". For the cultural issue, Metro TV framed it as "Pendet dance being claimed" and TV One used "Malaysia claims". However, TVRI framing is different compared to Metro TV and TVRI. For the Ambalat issue, TVRI used the "President frame", which is the negative reputation of Malaysia based on the President SBY opinion. TVRI uses the frame "Diplomacy lane" on Ambalat issue and the frames "SBY angry" and "SBY protest" in cultural issue.

The factors of media ownership and the ideology practice by television also influent the framing in television. Metro TV and TV One, owned by national politicians, Surya Paloh and Aburizal Bakrie, frame Malaysia related issue more by political consideration than economic or social factors.

Based on the process of 'Television News' analysis, the verbal and non-verbal elements will influence framing to complement each other. This situation showed in the news reporting of Metro TV and TV One, where both stations used the verbal and non-verbal framing to emphasize the message delivered. Framing by Metro TV and TV One not only want to attract public but also raise the nationalism through strategies like music or patriotic songs. The nonverbal frame (audio-visual) did by Metro TV and TV One emphasize the verbal faming (text). TVRI is tends to use sound bite presentation, from the President to emphasize on verbal framing (text). Thus, the verbal and non-verbal framing analysis can be combined.

Through triangulation, the television news framing is dominantly influent by reporter, media owner, and even the political system. The television framing tendency for Metro TV, TV One, and TVRI is similar; they used the framing strategy verbal (script) and nonverbal (audio-visual). Television also has reporter framing which based on the understanding, knowledge and profession among the television workers. Reporters do the framing in his daily practical works, such as when to choose picture, or when to decide to do interview. The reports framing will continue and repeated to create media framing.

Few factors influence the framing, such as reporter, media routine, media owner, political system, and the system of broadcasting. The most important factor for Metro TV, TV One and TVRI framing is the media owner. The owner is generally affected by the political and the broadcasting system since the era of Reformasi. With the liberation of media industry during the period, conglomerate like Metro TV and TV One, which is owned by businessman-politician Surya Paloh and Aburizal Bakrie are being established and rapidly successful. As the candidates for the Presidential election in 2014 Surya Paloh and Aburizal use the media for the political and business purposes. Only TVRI tends to be influenced by state policies and instruction from the President.

According to triangulation and news reporting model of framing analysis, ideological factor also affect the media framing. Behind the broadcast of news, media is framed with certain motivation through pictures and voice. This motivation is shown in news reporting which tend to attack Malaysia. Metro TV, TV One and TVRI take the action based on political ideology compared to economic or social factor. Basic political ideology, especially nationalism became the first thing to consider in media framing.

\section{References}

Ah Eng Lai, Francis Leo Collins \& Brenda S. A. Yeoh (2013). Migration and diversity in Asian contexts. Singapore: Institute of Southeast Asian Studies.

Entman, R. M. (1991). Framing United-States coverage of international news-contrast in narratives of the KAL and Iran Air incidents. Journal of Communication, 41 (4), 6-27.

Entman, R.M. (1993). Framing: Toward clarification of a fractured paradigm. Journal of Communication, 43 (4), 51-58.

Gamson, William A. and Andre Mogdiliani. (1989). Media discourse and public opinion on nuclear power: A constructionist approach. American Journal of Sociology, 95, 1-37.

Glasser, B.G. \& Strauss, A.L. (1971). The discovery of grounded theory: Strategies for qualitative research. Chicago: Aldine-Atherton, (Original work published in 1967).

Hallin, Daniel C. (1986). The uncensored war: The media and Vietnam. New York: Oxford University Press.

Hulteng, J.L. (1985). The messenger's motives: Ethical problems of the news media. Englewood Cliffs, NJ: Prentice-Hall.

lyengar, S. (1991). Is anyone responsible? How television frames political issues. Chicago: University of Chicago Press.

Kazmierczak, Elizabeth T. (2001). A semiotic perspective on aesthetic preferences, visual literacy, and information design. Information 
Design Journal, 10(2), 176-187.

Liebes, Tamar. (1998). Media, ritual and identity. Philadelphia: Taylor \& Francis.

Messaris, Paul \& Abraham, Linus. (2001). The role of images in framing news stories. In Reese, Stephen D. \& Gandy, Oscar H., \& Grant, August E. Framing public life: Perspectives on media and understanding of the social world. (215-226). Philadelphia: Taylor \& Francis.

Mulyana, Deddy. (2011). IImu komunikasi: Suatu pengantar. Bandung: Remaja Rosdakarya.

Sen, Krishna and David T Hill. (2007). Media, culture and politics in Indonesia. Singapore: Oxford University Press.

Syed Othman Syed Omar. (1999). Tentera Malaysia dalam era konfrontasi. Bangi: Penerbit Universiti Kebangsaan Malaysia.

Tagg, John. (1988). The burden of representation. Amherst: University of Massachusetts Press.

Tuchman G (1978). Making news: A study in the construction of reality. New York: The Free Press.

Van Gorp, B. (2005). Where is the frame? Victims and intruders in the Belgian press coverage of the asylum issue. European Journal of Communication, 20, 485-508.

Van Gorp, B. (2010). Strategies to take subjective out of framing analysis. In P. D'Angelo and J. A. Kuypers, Doing news framing analysis: Empirical and theoretical perspectives (pp.85-109). New York: Routledge. 